\title{
MODEL PENGADAAN BAHAN BAKU KURMA SALAK MENGGUNAKAN TEKNIK LOT for LOT
}

\author{
Imam Gazali, Moh. Fuad FM*, Banun Diyah Probowati \\ Program Studi Teknologi Industri Pertanian, Fakultas Pertanian, Universitas Trunojoyo Madura \\ * email korespondensi: mfuadfm@gmail.com
}

\begin{abstract}
The raw material is absolutely a need for a company to smooth production process. Procurement of raw materials is a major factor in the production process activities. One measure of the performance of control of raw material procurement is to minimize the cost. This study was conducted to determine and specify in providing a more economical raw materials between methods of this industry and Lot for Lot Technical of Material Requirement Planning. Calculation of the total cost of raw material requirement by considering the cost of purchase and cost of ordering. The data used to calculate the total cost of procurement of products obtained from the data demand of snake fruits are translated based on the structure of the product to determine the need for raw materials. Material Requirement Planning Methods with Lot for Lot technical generate total procurement costs are lower than the method of this industry. The total cost of procurement by the method of the company amounted to Rp 5,396,000.00 and Rp 5,331,600.00 of lot for lot. The savings that can be generated by lot for lot is Rp.160.400 or 2.97\%. Based on the results of the calculations are more economical method to be applied in industry with Lot for Lot.
\end{abstract}

Keywords : Procurement of Raw Materials, Material Requirement Planning, Lot for Lot

\section{PENDAHULUAN}

Tanaman salak (Salacca edulis) adalah tanaman asli Indonesia dan merupakan salah satu jenis buah tropis yang banyak digemari dan banyak tersebar di seluruh kepulauan nusantara. Di Indonesia, ada banyak jenis komoditas buah tropis yang dapat diolah lebih lanjut menjadi produk yang bermutu serta bernilai tinggi, salah satunya adalah salak. Salak merupakan salah satu tanaman buah yang disukai dan mempunyai prospek baik untuk diusahakan (Rachmawati, 2010).

Perkembangan industri kurma salak di Indonesia cukup pesat, hal ini disebabkan tingginya permintaan pasar terhadap konsumsi kurma salak, seperti dicontohkan kebutuhan salak di Kabupaten Bangkalan sebesar 582,34 kg pada Tahun 2013. Permintaan pasar yang besar memberi peluang bagi pengusaha dalam membuka industri kurma salak. Semakin banyaknya industri kurma salak mengakibatkan persaingan perusahaan yang semakin ketat. Suatu perusahaan akan dapat bersaing dengan perusahaan lainnya dalam memenuhi permintaan apabila perusahaan mampu menciptakan sistem produksi yang lancar dan efisien. Salah satu faktor yang mendukung lancarnya proses produksi adalah pengadaan bahan baku (Muzammah, 2013).

Kelompok Tani Ambudi Makmur 2 Bangkalan merupakan salah satu industri yang bergerak dalam bidang pengolahan buah salak. Kelompok Tani Ambudi Makmur 2 Bangkalan melakukan pengadaan bahan baku sesuai dengan target produksi yang ingin dicapai. Tanggung jawab terhadap pengadaan bahan baku dilakukan oleh pihak manajer dan bagian stok barang. Kebutuhan bahan baku sangat ditentukan oleh permintaan konsumen. Pola permintaan konsumen terhadap produkproduk Kelompok Tani Ambudi Makmur 2 bersifat tidak tetap. Adanya permintaan yang tidak tetap akan menyebabkan permasalahan dalam menentukan kebutuhan bahan baku yang optimal. Kelompok Tani Ambudi Makmur 2 saat ini memproduksi berbagai macam jenis produk olahan salak yaitu kurma salak, kismis salak, dodol salak, sirup salak 
dan selai salak. Pada penelitian ini hanya fokus pada kurma salak saja, karena produk kurma salak ini yang paling banyak membutuhkan bahan baku salak. Kebutuhan bahan baku salak bulan Mei 2014 di kelompok tani ambudi makmur 2 adalah kurma salak 195,32 kg, dodol salak 35,48 kg, kismis salak 39,56 kg, selai salak 9,2 kg, dan sirup salak 55,68 kg (Saleh, 2014).

Suatu perusahaan sering kali mengalami masalah dalam pengadaan material (bahan baku), diantaranya adalah pengadaan yang terlalu banyak atau bahkan terjadi sebaliknya, maka diperlukan suatu sistem pengadaan material yang baik, dengan mengadakan perencanaan kebutuhan material dengan metode MRP yang perencanaannya diawali dengan mmelakukan peramalan akan jumlah permintaan untuk waktu yang akan datang (Astana, 2007).

Pengadaan bahan baku merupakan faktor utama dalam melakukan kegiatan proses produksi. Ketiadaan bahan baku yang cukup dapat menghambat berlangsungnya proses produksi perusahaan, oleh karena itu faktor pengadaan bahan baku menjadi hal yang sangat penting dalam memenangkan persaingan. Pengadaan bahan baku berkaitan dengan biaya oprasional suatu perusahaan. Semakin tinggi volume pengadaan berdampak pada biaya yang harus disediakan. Biaya yang dikeluarkan bukan hanya biaya penyimpanan digudang, melainkan harus diperhitungkan pula biaya yang dikeluarkan mulai dari pemesanan sampai barang tersebut masuk ke dalam proses produksi dan kembali ke gudang sampai barang jadi (Ristono, 2009).

\section{Metode Material Requirement}

Planning (MRP) merupakan salah satu metode manajemen pengadaan bahan baku dan digunakan untuk memudahkan penyusunan jadwal kebutuhan setiap komponen yang dibutuhkan dan digunakan sebagai alat pengendalian produksi dengan menggunakan teknik lot for lot (L-F-L). Teknik ini mencoba meniadakan ongkos simpan barang dengan memesan sejumlah barang yang dibutuhkan. Pesanan barang tersebut diatur sedemikian rupa sehingga akan datang tepat saat dibutuhkan, dengan demikian memudahkan penyusunan jadwal kebubutuhan setiap komponen yang dibutuhkan. Kelebihan lot for lot merupakan teknik ukuran lot diskrit karena hanya memenuhi permintaan sesuai dengan yang telah direncanakan dalam periode tertentu dan kelemahan teknik ukuran lot diskrit ini adalah bila dimasa yang akan datang (periode mendatang) terjadi lonjakan permintaan, maka harus dilakukan perhitungan nilai kembali. Selain itu juga sebagai alat pengendalian produksi dan pengadaan bahan baku (Nasution dan Prasetiawan, 2008).

Tujuan dari penelitian ini adalah untuk memperoleh gambaran pengadaan bahan baku pada industri kurma salak dan untuk memperoleh pengadaan bahan baku dengan metode Material Requirement Planning (MRP) dengan teknik lot for lot pada industri kurma salak.

\section{METODE PENELITIAN}

Penelitian ini dilaksanakan di Kelompok Tani Ambudi Ambudi Makmur 2 yang terletak di Dusun Morkolak timur Desa Kramat Kabupaten Bangkalan. Penelitian ini dimulai pada bulan Oktober - April 2014 dan data yang digunakan dalam perencanaan yaitu selama 3 bulan mulai bulan Februari sampai April 2014.

Tahapan penelitian ini adalah sebagai berikut :

1. Pengumpulan data tentang pengadaan bahan baku diperoleh dari Kelompok Tani Ambudi Makmur 2 Kabupaten Bangkalan seperti data biaya pemesanan, kebutuhan bahan baku, lead time, bill of material (BOM) dan data harga bahan baku.

2. Pengolahan data meliputi menghitung biaya pengadaan bahan baku metode perusahaan, menghitung biaya pengadaan bahan baku metode Material Requirement Planning (MRP) teknik lot for lot dan Bill of material (BOM).

3. Perbandingan antara kedua metode yaitu metode perusahaan dengan metode Material Requirement Planning (MRP) teknik lot for lot yang bertujuan untuk mendapatkan metode terbaik.

\section{HASIL DAN PEMBAHASAN}

\section{Pengadaan dan Pengendalian Bahan Baku Industri Kurma Salak}

Setiap perusahaan yang mempunyai kegiatan produksi membutuhkan persediaan 
bahan baku, dengan persediaan bahan baku yang dimiliki perusahaan dapat menjalankan proses produksi untuk memenuhi permintaan konsumen dan kebutuhan akan suatu barang dengan tepat waktu, dalam suatu sistem produksi, salah satu faktor kelancaran proses produksi yaitu ketersediaan bahan baku. Perusahaan memerlukan pengendalian bahan baku agar proses produksi dapat berjalan dengan lancar dan efisien.

Kelompok Tani Ambudi Makmur 2 melakukan pengendalian persediaan bahan baku sesuai dengan target produksi yang ingin dicapai. Saat musim panen raya tiba, Kelompok Tani Ambudi Makmur 2 sering mengambil kebijakan membeli bahan baku dengan kuantitas yang besar. Pembelian bahan baku dengan kuantitas besar hanya didasarkan pada harga bahan baku yang lebih murah dari biasanya tanpa mempertimbangkan akan biaya-biaya persediaan yang lainnya. Tentunya hal itu menjadi permasalahan bagi setiap perusahaan karena persediaan bahan baku yang melebihi kebutuhan akan menyebabkan meningkatnya biaya yaitu biaya penyimpanan. Kekurangan persediaan juga tidak baik karena akan menyebabkan terhambatnya suatu proses produksi sehingga tidak mampu memenuhi permintaan konsumen yang mengakibatkan beralihnya kepercayaan konsumen dan kerugian akibat kehilangan konsumen.

\section{Produk Kelompok Tani Ambudi Makmur} 2

Kelompok Tani Ambudi Makmur 2 merupakan perusahaan yang menghasilkan berbagai produk. Produk Kelompok Tani Ambudi Makmur 2 termasuk dalam obyek yang berwujud yaitu berupa barang. Berbagai macam produk Kelompok Tani Ambudi Makmur 2 berasal dari tanaman salak.

Kelompok Tani Ambudi Makmur 2 mengolah buah salak menjadi produk makanan camilan yang lebih tahan lama/awet dan memiliki harga jual yang lebih tinggi dibanding dengan buah salak itu sendiri. Produk-produk Kelompok Tani Ambudi Makmur 2 diantaranya kurma salak, dodol salak, sirup salak, kismis salak dan selai salak

\section{Permintaan Produk Kurma Salak}

Berdasarkan pola permintaan pada Kelompok Tani Ambudi Makmur 2 yang bersifat tidak tetap (berfluktuatif) maka metode MRP teknik lot for lot dapat digunakan untuk menyelesaikan masalah pada pengendalian pengadaan bahan baku di Tani Ambudi Makmur 2. Pola permintaan produk kurma salak dari bulan Februari-April 2014.

Tabel 1. Permintaan Kurma Salak Kemasan $0,25 \mathrm{~kg}$

\begin{tabular}{|c|c|c|c|}
\hline \multirow[t]{2}{*}{ Minggu } & \multicolumn{3}{|c|}{$\begin{array}{c}\text { Permintaan Kurma Salak Per } \\
\text { Kemasan } 0,25 \mathrm{~kg}\end{array}$} \\
\hline & Februari & Maret & April \\
\hline 1 & 110 & 40 & 30 \\
\hline 2 & 82 & 60 & 34 \\
\hline 3 & 170 & 45 & 20 \\
\hline 4 & 75 & 45 & 88 \\
\hline Total & 432 & 195 & 172 \\
\hline
\end{tabular}

Sumber data : Kelompok Tani Ambudi Makmur 2 (2014)

\section{Kebutuhan Bahan Baku}

Kebutuhan bahan baku berdasarkan rencana produksi kurma salak yang didapatkan dari permintaan konsumen akan produk salak. Dari jumlah pesanan roti dan jadwal produksi diperoleh kebutuhan bahn baku yang harus dipenuhi untuk mendapatkan produk akhir sesuai permintaan. Kebutuhan bahan baku pada industri kurma salak dapat dilihat dari penggunaan bahan baku dari tiap periode dan diwujudkan dalam bentuk frekuensi pembelian bahan baku salak.

Tabel 2. Penggunaan Bahan Baku Salak

\begin{tabular}{cc}
\hline Bulan & Salak $(\mathrm{kg})$ \\
\hline Februari & 393 \\
Maret & 449 \\
April & 483 \\
\hline
\end{tabular}
yang ditetapkan Kelompok Tani Ambudi Makmur 2 berupa jadwal kebutuhan kotor untuk setiap periode, jadwal penerimaan dan persediaan di tangan untuk produk akhir.

Jadwal kebutuhan kotor sesuai dengan tabel 3 selama 3 bulan yaitu mulai 
bulan Februari sampai April 2014 total kebutuhan kotor sebesar 1325 unit dan jadwal penerimaan 448 unit, diperoleh dari jumlah kebutuhan bersih ditambah waktu ancang produksi operasi yang menghasilkan item jadwal penerimaan.

Tabel 3. Jadwal kebutuhan kotor

\begin{tabular}{|l|l|l|l|l|l|l|l|l|l|l|l|l|l|}
\hline Periode & 1 & 2 & 3 & 4 & 5 & 6 & 7 & 8 & 9 & 10 & 11 & 12 & Total \\
\hline $\begin{array}{l}\text { Kebutuhan } \\
\text { kotor }\end{array}$ & 195 & & 198 & & 214 & & 235 & & & 240 & 243 & & 1325 \\
\hline $\begin{array}{l}\text { Jadwal } \\
\text { penerimaan }\end{array}$ & & 448 & & & & & & & & & & & \\
\hline $\begin{array}{l}\text { Persediaan } \\
\text { di Tangan }\end{array}$ & & & & & & & & & & & & & \\
\hline
\end{tabular}

Tabel 4. Perhitungan Keseluruhan kebutuhan bersih

\begin{tabular}{|l|l|l|l|l|l|l|l|l|l|l|l|l|l|}
\hline Periode & 1 & 2 & 3 & 4 & 5 & 6 & 7 & 8 & 9 & 10 & 11 & 12 & Total \\
\hline $\begin{array}{l}\text { Kebutuhan } \\
\text { kotor }\end{array}$ & 195 & & 198 & & 214 & & 235 & & & 240 & 243 & & 1325 \\
\hline $\begin{array}{l}\text { Jadwal } \\
\text { penerimaan }\end{array}$ & & 448 & & & & & & & & & & & 448 \\
\hline $\begin{array}{l}\text { Persediaan di } \\
\text { Tangan }\end{array}$ & 110 & 82 & 170 & 75 & 40 & 60 & 45 & 45 & 30 & 34 & 20 & 88 & 799 \\
\hline $\begin{array}{l}\text { Kebutuhan } \\
\text { bersih }\end{array}$ & 0 & 0 & 0 & 0 & 0 & 0 & 0 & 0 & 0 & 11 & 243 & & 254 \\
\hline
\end{tabular}

Tabel 5. Biaya Pesan bahan baku per pesanan

\begin{tabular}{lllll} 
Nama & \multicolumn{4}{c}{ Biaya Pemesanan $(\mathrm{Rp})$} \\
& $\begin{array}{l}\text { Biaya } \\
\text { administrasi }\end{array}$ & Biaya telepon & $\begin{array}{l}\text { Biaya } \\
\text { pemindahan }\end{array}$ & Total \\
\hline Salak & 5.000 & 1.000 & 10.000 & 16.000
\end{tabular}

Berdasarkan tabel 4, kebutuhan kotor mencapai 1325 unit dan kebutuhan bersih mencapai 254 unit dengan jadwal penerimaan sebesar 448 unit. Hasil keseluruhan perhitungan kebutuhan bersih yaitu kebutuhan kotor 1325 unit, jadwal penerimaan 448 unit, persediaan di tangan 799 unit dan kebutuhan bersih 254 unit.

\section{Biaya Pengadaan Bahan Baku}

\section{Biaya Pembelian}

Besarnya biaya pembelian bahan baku setiap item berbeda sesuai dengan jumlah dan harga bahan baku per unit. Biaya pembelian bahan baku berdasarkan jumlah bahan baku yang dibeli dikalikan dengan harga per unit. Perhitungan biaya pembelian bahan baku pada industri kurma salak yaitu sebesar Rp 5.300.000,00 dengan harga salak per $\mathrm{kg}$ sebesar Rp 4.000,00 dengan jumlah pembelian sebesar $1.325 \mathrm{~kg}$.

\section{Biaya Pemesanan}

Biaya pemesanan bahan baku salak yang dikeluarkan oleh Kelompok Tani Ambudi Makmur 2 meliputi biaya administrasi, biaya komunikasi dan biaya pemindahan bahan baku. Biaya komunikasi adalah biaya telepon yang digunakan untuk menghubungi pemasok.

Biaya pemesanan dipengaruhi oleh frekuensi pemesanan (jumlah berapa kali pesan dalam satu horizon perencanaan selama 3 bulan yaitu bulan Februari sampai April). Biaya pemesanan ini tidak dipengaruhi besarnya jumlah bahan baku yang dipesan. Perincian biaya pemesanan bahan baku salak pada 
Kelompok Tani Ambudi Makmur 2 dapat dilihat pada Tabel 5.

Biaya administrasi pada tiap pemasanan didapatkan dari biaya pengetikan pemesanan, biaya cetak (bahan baku yang dipesan dan bahan baku yang ada di gudang pada saat pemesanan). Biaya telepon deperoleh dari biaya ratarata yang terpakai pada saaat melakukan pemesanan dengan pemasok tiap sekali pesan. Sedangkan biaya pemindahan digunakan untuk membayar buruh untuk memindahkan bahan baku dari angkutan sampai kegudang pada saat penerimaan pesanan. Untuk biaya pengangkutan bahan baku salak tidak termasuk dalam biaya pemesanan karena ditanggung oleh pihak pemasok dari gudang pemasok sampai ke industri Kelompok Tani Ambudi Makmur 2.

Biaya pemesanan yaitu $\mathrm{Rp}$ 96.000,00 didapatkan dari frekuensi pemesanan salak dalam horizon perencanaan selama 3 bulan yaitu bulan Februari sampai April sebanyak 6 kali.

Biaya pengadaan bahan baku diperoleh dari penjumlahan biaya pemesanan dengan biaya pembelian. Besarnya kuantitas pemesanan dan frekuensi pemesanan dapat dipengaruhi biaya pengadaan bahan baku. Hal ini desebabkan semakin besar kuantitas pemesanan semakin besar pula biaya pembeliannya. Begitu juga semakin tinggi frekuensi pemesanan, maka biaya pemesanan juga tinggi yang menyebabkan biaya pengadaan bahan baku juga tinggi. Biaya pengadaan bahan baku pada industri kurma salak selama bulan Februari-April sebesar Rp. 5.396.000,00.

\section{Pengadaan Bahan Baku Berdasarkan Metode MRP dengan teknik lot for lot}

Kuantitas pesanan untuk bahan baku salak metode MRP lebih kecil dari pada metode perusahaan. Hal ini dapat meminimasi biaya pembelian pada bahan baku salak. Pada perusahaan kuantitas salak yang tinggi dikarenakan pemesanan dilakukan dengan memperkirakan banyaknya permintaan saja tetapi tidak menghitung kebutuhan bersih.

Pengadaan Bahan Baku Berdasarkan

Metode MRP teknik lot for lot dapat dilihat pada tabel 6. Material Requirement Planning (MRP) dalam penerapannya diperlukan suatu jadwal induk produksi pada industri kurma salak berdasarkan permintaan konsumen yang diperoleh dari daftar pesanan terhadap produk Salak. Jadwal induk produksi untuk menentukan jumlah produksi yang dibutuhkan untuk produk akhir beserta periode waktunya dalam suatu perencanaan. Penelitian ini dapat menunjukkan kebutuhan bahan baku untuk menghasilkan produk akhir pada tiap periode dalam suatu perusahaan.

Tabel 6. Pengadaan bahan baku metode MRP dengan teknik lot for lot 


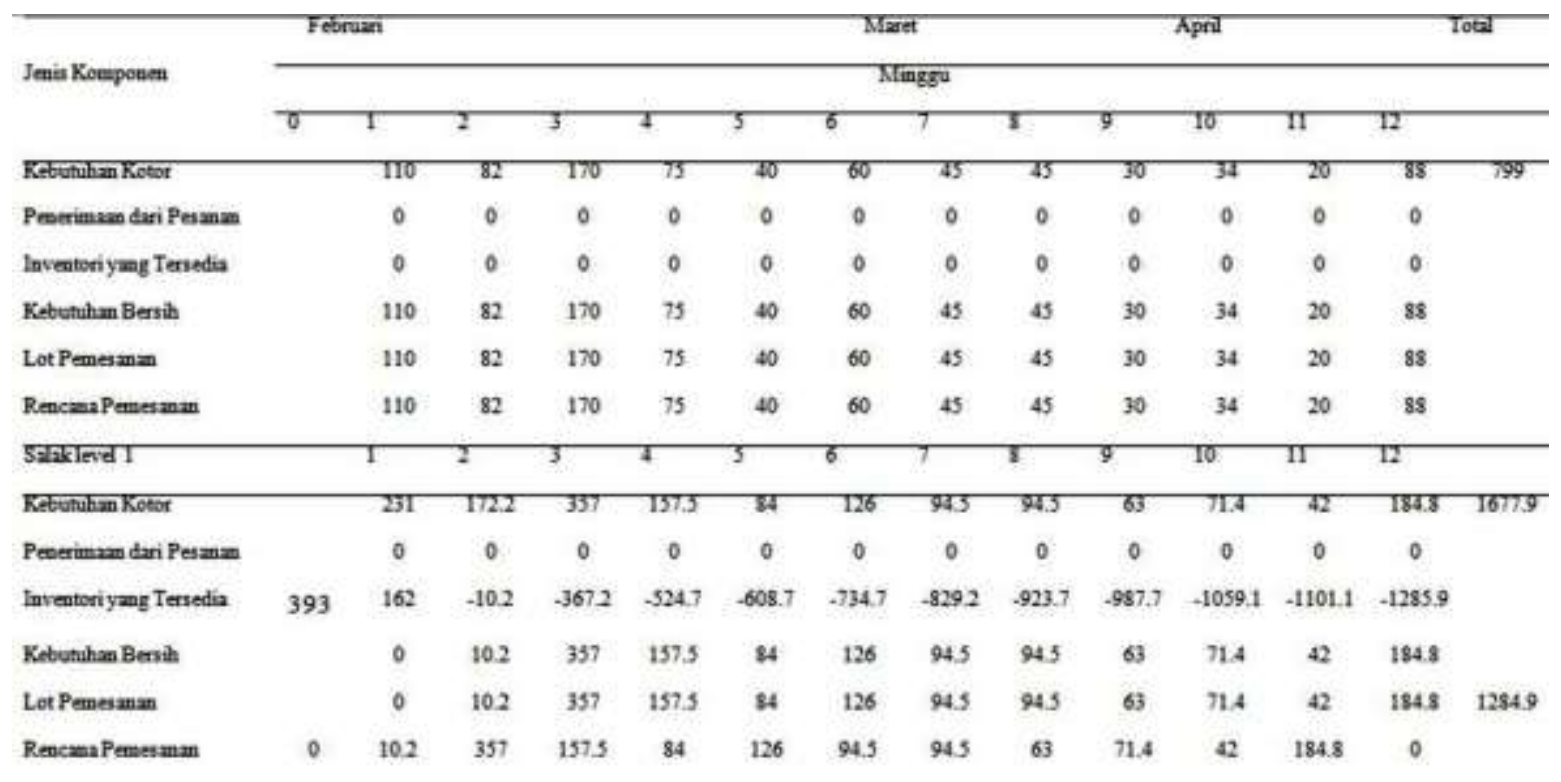

Kebutuhan bahan baku berdasarkan rencana produksi kurma salak yang didapatkan dari permintaan konsumen. Kebutuhan bahan baku pada industri kurma salak dapat dilihat dari penggunaan bahan baku dari tiap periode.

Tabel 7. Penggunaan bahan baku salak pada bulan Februari-April 2014.

Penggunaan Bahan

\section{Baku}

\begin{tabular}{ll}
\hline Bulan & Salak $(\mathrm{kg})$ \\
Februari & 393 \\
Maret & 449 \\
April & 483 \\
\hline
\end{tabular}

Penggunaan bahan baku tabel 7 yang menyatakan bahwa salak tiap bulannya mengalami kenaikan produksi dalam penggunaannya, sehingga dapat dilihat pada struktur produk yang memberikan informasi tentang kebutuhan bahan baku salak tersebut.

Struktur produk berisi tentang informasi yang mengidentifikasi semua komponen dan sub komponen yang akan digunakan untuk menghasilakan produk akhir. Bahan baku yang akan direncanakan persediaannya adalah bahan baku yang diperlukan untuk pembuatan kurma salak.

Catatan persediaan industri kurma salak menunjukkan bahwa persediaan awal pada bulan Februari yang diperoleh dari sisa persediaan pada bulan sebelumnya. Jumlah persediaan awal bahan baku yaitu sebanyak $393 \mathrm{~kg}$ yaitu berdasarkan persediaan awal bahan baku pada bulan Februari

Waktu tunggu pengadaan bahan baku merupakan waktu yang dibutuhkan sejak bahan baku dipesan sampai bahan baku tersebut diterima atau tiba di industri kurma salak. Waktu tunggu untuk pemesanan sampai penerimaan bahan baku pada industri kurma salak adalah satu minggu.

Pengadaan bahan baku dengan metode MRP teknik lot for lot menentukan pemesanan yang besarnya sama dengan kebutuhan bersih pada periode perencanaan. Metode ini dapat meminimalkan biaya pengadaan karena kuantitas pemesanan bahan baku jumlahnya sama dengan kebutuhan dan melakukan pemesanan bahan baku sesuai dengan waktu tunggu sehingga bahan akan datang tepat pada saat dibutuhkan. Kebutuhan bersih peda penelitian ini diperoleh dari penggunaan bahan baku yang merupakan kebutuhan kotor dikurangi dengan persediaan awal.

Penentuan jumlah pesanan dan rencana pemesanan bahan baku metode MRP teknik lot for lot menunjukkan hasil pemesanan sebanyak 12 kali yaitu untuk bahan baku salak sesuai dengan kebutuhan tiap periode dan lead time. 
Frekuensi pemesanan bahan baku salak besarnya sama karena mempunyai lead time yang sama dan persediaan awal yang lebih kecil dari kebutuhan sehingga harus dilakukan pemesanan. Metode ini melakukan pembelian bahan baku dengan kuantitas yang berbeda-beda sesuai dengan jumlah kebutuhan.

Biaya pengadaan bahan baku metoda MRP teknik lot for lot didapat dari penjumlahan biaya pemesanan dengan biaya pembelian. Biaya pemesanan dihasilkan dari frekuensi pemesanan dikalikan dengan biaya per pesanan. Biaya pemesanan berdasarkan metode lot for lot yaitu frekuensi pemesanan sebanyak 12 dikalikan dengan biaya pesan Rp. 16.000,00 sehingga menghasilkan biaya pemesanan sebesar Rp. 192.000,00. Rencana pemesanan juga dipengaruhi oleh lead time. Biaya pembelian bahan baku salak mencapai Rp 5.139.600,00 dengan kuantitas pembelian $1.284,9 \mathrm{~kg}$. Berdasarkan biaya pembelian dan biaya pemesanan dapat diketahui besarnya biaya pengadaan bahan baku dengan metode MRP teknik lot for lot yaitu sebesar $\mathrm{Rp}$ 5.331.600,00.

\section{Perbandingan Pengadaan Bahan Baku Perusahaan dengan Metode MRP Teknik Lot for Lot}

Perusahaan membeli bahan baku dengan kuantitas yang melebihi kebutuhan dengan menghubungkan bahwa bahan baku salak memiliki keawetan yang cukup lama apabila penyimpanan dilakukan dengan benar. Pembelian bahan baku melebihi kebutuhan yang dilakukan industri kurma salak ini dapat memenuhi permintaan konsumen apabila terdapat permintaan secara mendadak. Hal ini ternayta menyebabkan biaya pengadaan bahan baku lebih tinggi dibandingkan metode MRP lot for lot. Penumpukan bahan baku juga beresiko mengakibatkan bahan baku tersebut rusak jika disimpan lama pada kondisi yang kurang sesuai. Bahan baku salak merupakan bahan yang mudah rusak apabila disimpan terlalu lama.

Metode MRP lot for lot melakukan pemesanan sesuai dengan jumlah kebutuhan karena mengingat bahan baku yang berupa hasil pertanian umumnya tidak dapat disimpan lama atau mudah rusak. Metode ini juga menunjukkan biaya pengadaan yang kecil, karena tidak ada biaya penyimpanan bahan baku. Semua bahan baku yang dipesan pada periode tertentu langsung digunakan pada periode itu juga. Kualitas bahan baku akan lebih terjamin karena tidak disimpan dalam waktu yang lama, sehingga diharapkan kurma salak yang dihasilkan lebih berkualitas.

Pengadaan bahan baku perusahaan dan metode MRP lot for lot terdapat perbedaan pada biaya pengadaan bahan baku. Salah satu komponen biaya pengadaan bahan baku berupa biaya pembelian dengan metode MRP teknik lot for lot terdapat selisih biaya sebesar Rp. 160.400,00 lebih kecil dibandingkan dengan biaya pembelian bahan baku berdasarkan metode perusahaan. Hal ini berarti dengan menggunakan metode MRP lot for lot terjadi penghematan sebesar 2,97\% dari metode yang diterapkan industri kurma salak ini.

\section{KESIMPULAN}

Pengadaan bahan baku dengan menggunakan metode perusahaan selama 3 bulan mulai bulan Februari sampai April sebanyak 6 kali pembelian dengan total biaya sebesar Rp. 5.396.000,00.

Pengadaan bahan baku dengan menggunakan metode Material Rquirement Planning (MRP) teknik lot for lot pada bulan Februari sampai April sebanyak 12 kali pembelian dengan total biaya sebesar $\mathrm{Rp}$. 5.331.600.

Penggunaan metode Material Rquirement Planning (MRP) teknik lot for lot mampu menghemat biaya pengadaan bahan baku sebesar Rp. 160.400 atau selisih 2,97\% jika dibandingkan dengan metode yang diterapkan perusahaan.

\section{DAFTAR PUSTAKA}

Asrori, H. 2010. Analisis pengendalian persediaan bahan baku kayu sengon PT Abirama Kresna dengan metode EOQ [Skripsi]. Fakultas ekonomi. Surakarta: Universitas Sebelas Maret.

Astana, NY. 2007. Perencanaan persediaan bahan baku berdasarkan metode material requirement planning (MRP). Jurnal ilmiah vol.11, no.02. juli 2007. 
Jurusan Teknik Sipil. Fakultas Teknik. Denpasar: Universitas Udayana.

Bahagia, SN. 2006. Sistem Inventori. Bandung: Institut Teknologi Bandung.

Baroto, T. 2002. Perencanaan dan pengendalian produksi. Jakarta: Galia Indonesia.

Dinas Pertanian Dan Peternakan, 2014. Perbandingan luas tanam $\left(\mathrm{H}_{2}\right)$, luas panen $\left(\mathrm{H}_{2}\right)$, produktifitas $(\mathrm{Kw})$ dan produksi (Kw) tanaman tahunan. Kabupaten Bangkalan: Laporan Tahunan.

Indrajid, E dan Djokopranoto. 2003. Manajemen Persediaan. Jakarta: Gramedia Widia Sarana Indonesia.

Jaya, SS. Octavia, T dan Widyadana, GA. Model persediaan bahan baku Multi item dengan mempertimbangkan masa kadaluarsa, unit diskon dan permintaan permintaan yang tidak konstan. Jurnal Teknik Industri, Vol. 14, No. 02, Desember 2012. Di akses tanggal 13 juni 2014.

Kusuma, H. 2003. Manajemen Produksi Perencanaan dan pengendalian Produksi. Yogyakarta. ANDI OFFSET.

Muzammah, WN. 2013. Pengendalian persediaan bahan baku dengan metode algoritma wagner within dan silver meal [Skripsi]. Fakultas Pertanian. Bangkalan: Universitas Trunojoyo Madura.

Nurani, G. 2013. Perhitungan pengadaan bahan baku roti tawar dengan metode material requirement planning (MRP)

[Skripsi]. Fakultas Pertanian.

Bangkalan: Universitas Trunojoyo

Madura.

Nasution, AH dan Prasetyawan, Y. 2008. Perencanaan dan pengendalian produksi. Cetakan Pertama. Yogyakarta: Graha Ilmu.

Ristono, A. 2009. Manajemen Persediaan. Cetakan Pertama. Yogyakarta: Graha Ilmu.

Robyanto, CB. Antara, M dan Dewi, RK. 2013. Analisis persediaan bahan baku tebu pada pabrik gula pandji. E-Jurnal Agribisnis dan Agrowisata. Vol. 02, No. 01, Januari 2013. Fakultas Pertanian. Bali: Universitas Udayana.

Rovianty, AN, 2007. Analisis penerapan material requirement planning (MRP) dalam upaya mengendalikan persediaan bahan baku daging pada long horn steak \& ribs [Skripsi]. Fakultas bisnis dan Manajemen. Bandung: Universitas Widyatama.

Soetomo, M. 1990. Teknik Bertanam Salak. Cetakan Pertama. Bandung: Sinar Baru.

Siregar, AA. 2012. Analisis Nilai Tambah Pengolahan Salak. Jurnal ilmiah. Fakultas Pertanian. Medan: Universitas Sumatra Utara. 